\title{
Taking Matters into our Own Hands: Humanizing Slovak Translation History
}

\author{
"Home are the hands held upon the table \\ [...] \\ the only ones who create history."
}

- M. Válek (trans. I. T.)

The poem fragment we have taken for our motto is often interpreted as the author's polemics with the view of history as a playground of impersonal forces beyond individual human control (Bagin 1982)1. This view, it seems to us, is in direct contradiction to the goal-oriented, personal-responsibility-based, and socially complex act of translation. One could argue, however - and, indeed, many already have (most notably Bastin, Bandia 2006; Rundle 2012; Rizzi, Lang, Pym 2019) - that the history of translation has traditionally relied too much on literary and translation studies methodologies and concepts, thereby ignoring the historically complex social relations which give rise to and are influenced by translations.

Translation history has enjoyed a rather prominent place in Slovak translation studies, since historical research on translations basically stood at its

1 Due to the historical nature of our research, we have decided to include years of publication after each reference. We have also decided to do so to avoid confusion, since in the second half of the paper we mention many names of scholars whose work has not been published to its full extent or, on the contrary, whose many works reflect the outlined tendency. In the end we have used the following system of referencing: Whenever there is a year in brackets mentioned after the author's name, the particular work is mentioned in our References; if no year is mentioned after the name, we are just pointing out the person's work in general. 
beginning. In this study, we attempt at a selective overview of past Slovak approaches to translation history with the view of construing possible lines of influence on the present and a view of possible future development. The underlying idea of our approach is illustrated in the mentioned motto: We view history (and, by extension, the history of ideas) as a process not governed by great (almost supernatural) rules - be it fate, Marxist class struggle, or progress - but rather as a series of small actions, their unpredictable outcomes, and, above all, contingency.

The first material we work with consists of older relevant Slovak translation studies and literary studies publications from which we have chosen texts that can be seen as watershed or liminal in that they demonstrate a shift in paradigms (see Snell-Hornby 2006), which in the late 1960 s was basically a shift from literary studies to the then-emerging new field of translation studies (known as translation theory at the time). Of course, our choice of the discussed publications is based on our interpretation of translation studies which we view as an independent, empirical, and interdisciplinary research field concerned with translation as a specific and autonomous communicational and historical phenomenon. Therefore, our list of scholars and notable publications is by no means exhaustive. As for material from the present, apart from referring to the most relevant publications, we have conducted a qualitative survey among Slovak scholars who research translation history and shall present their views in comparison to the past developments and influences.

Methodologically speaking, we shall attempt to conduct an archaeology of discourse. We view translation history as a historically embedded and socially restricted case (Saldanha, O'Brien 2013) of discourse with its own order (Foucault 1981) which can be properly understood only when adopting the principle of exteriority. As Marcelli has it, "no going under the discourse is permitted in archeology, since the stance of exteriority does not allow it; [it is necessary] to remain at the level of the utterances and examine their form of positivity" (2005: 90). Only when we view even influential theoretical works as historical documents, regardless of their present impact on the field, we are able to fully account for their historical value.

In our reconstruction of the development of Slovak translation history, we will talk about models. These are heuristic means which use similarity to help people infer relations between concepts and illustrate the patterns of a certain set of unknown variables on the basis of a set of known ones (see Krupa 1990).

2 Unless stated otherwise, all quotes from non-English language sources have been translated by the present authors. 
Of course, models are by nature approximations and are thus relative and suitable only for description. In our analysis, we shall adopt an anti-realist approach to models and argue that they are true "insofar as they describe the behavior of an empirically observable system" (Koperski 2019). As for translation history, we view the concept in two senses: a) the body of knowledge about the history of translation research has provided us with; b) the development vs. the state of the art of research on translation history (i.e. historiography).

\section{Translation history past}

Slovak translation history has been deeply influenced by Russian formalism and Czech structuralism, two humanities intellectual movements which, due to geopolitics and ideology, have had a rather complicated past in Slovakia.

\subsection{Formalism and historical poetics; structuralism and the scientific method in literary studies: the case of Mikuláš Bakoš}

When in 1918 the first Czechoslovak republic was established, Slovakia finally had the opportunity to build up its cultural institutions, which had been stagnant or practically non-existent during the Austro-Hungarian Empire. The tradition of Slovak literary studies until that time had existed mostly in the form of essayist, impressionist literary criticism or (later) positivist literary history. The Ukrainian-born Slovak literary scholar Mikuláš Bakoš (1914-1972) played the largest role in the establishment of structuralism and formalism in Slovakia. Bakoš started his career by translating the works of Russian formalists, many of whom had emigrated from the Soviet Union in the 1920 s and 1930 s and found refuge in Prague, Bratislava, or Vienna (e.g. Roman Jakobson, Petr Bogatyrev, Alexander Isachenko, or Nikolai Trubetzkoy) before moving on further West at the onset of WWII. Bakoš conducted his translational activities systematically and sought - in his own words: "[...] to enrich Slovak culture with the translations of groundbreaking literary theoretical works which will help further develop our literary studies, and, above all, to do that before the Czechs, so that it will be apparent that Slovaks are emancipating themselves [...] and finding their own way" (in Gáfrik 2016: 86).

Prague-educated Bakoš, however, was also a prominent structuralist who drew his inspiration from the leading figures of the Prague Linguistic Circle, such as Jan Mukařovský or formalist R. Jakobson (who lectured in Brno in the 1930s). Bakoš was also one of the main organizers and generational critics of Slovak avant-garde arts and surrealist poetry in the late 1930s and 1940s (see 
Bakoš 1969a), and in 1937 he co-founded the Bratislava-based structuralist scientific society of humanist intellectuals called the Society for Scientific Synthesis. The group spearheaded values of interdisciplinarity, rigid scientific methods and also (albeit unsuccessfully) sough to protect the progressive intellectual elite in the otherwise very conservative pre-WWII Slovakia (J. Bakoš 2005: 293). The tragic personal and professional "fate" of Mikuláš Bakoš encapsulates what happened to the Slovak structuralist and formalist traditions in the $20^{\text {th }}$ century.

Bakošs first groundbreaking work was the versological monograph Vývin slovenského verša od školy Štúrovej (Development of Slovak verse since Štúr's school, 1939), considered the first Slovak work on poetics with a consistent theoretical framework (Gáfrik 2016). In his approach, Bakoš relied heavily on formalist theory and interconnected it with some of Mukařovskýs structuralist concepts. This was a watershed publication in that it was a quantitative analysis of Slovak verse development and an introduction to historical poetics. The author deemed it unacceptable to separate poetics and literary history, since "this leads to a mechanistic separation of the literary work's constitutive elements from the historical perspective". He was convinced that historical poetics could bridge this methodological gap by examining "the internal conditions of literature development" (Bakoš 1966: 7).

The first edition of the book in 1939 consisted of only 500 copies, and its distribution was severely restricted; the regime of the fascist Slovak State at its worst regarded formalism as Jewish and Bolshevik and at its best as only partially acceptable and not fully compatible with the local literary studies tradition (see Gáfrik 2016). Bakoš sought to have a revised edition of the book published after the war, but managed to do so only after the 1948 communist takeover of the country. When after several bureaucratic obstructions the second edition of the book did finally come out in 1950, it was at the time of Stalinist Czechoslovakia with heavily controlled and centralized culture (Marušiak 2001). The edition was only 200 copies, was plagued with an even more limited distribution, and some books were even destroyed (Bakoš 1966: 17). The third edition came out during a time of steady de-Stalinization when a more liberal cultural policy was adopted (Tyšš 2017) and formalism and structuralism were being revisited, as literary scholars were attempting to overcome the stagnation their field experienced in the previous decade (Valentová 2017). 


\subsection{The 1960 s and the 1970s: Bakoš, Popovič, and the communicative approach in Nitra}

Slovak structuralism had survived the 1950 s in what Matejov and Zajac have called "discrete anonymity" (2005: 12). This in effect meant that several key literary studies works adopted its methodology and young scholars derived their approach from it, but nobody referred to it publicly. The fortunes of the structuralist (and eo ipso formalist) heritage changed in the 1960s - and, symbolically enough, so did the fortunes of Mikuláš Bakoš. In 1964, the Institute of World Literature and Languages was established at the Slovak Academy of Sciences, and Bakoš became its first director and principal researcher. In this context he managed to institutionalize his ideas on historical poetics and to streamline them into a comparative literature research program. More importantly, however, he also recruited and, as many attest to it (see Franek 2016), "raised" and supported a new generation of up-and-coming scholars who became the new proponents of structuralist methodology in the decades to come.

Bakošs aim was to create a coherent and objective research program which would help explain the historical development of Slovak literature in its relations to surrounding national literatures. In order to do so, he further expanded his older research into literary historical processes (Bakoš 1944). The fundamental question he sought to answer was how to objectively interpret literary history based on the dialectic relations between the internal development of literary forms and external, i.e. socio-cultural, factors impacting literature. To that end, Bakoš (1969b) developed a comparative literature research model of the literary process in which he argued that the following factors should be taken into account:

1) genesis of the literary work (social, literary, and individual preconditions);

2) structure (objective characteristics);

3) social function (concretization of the work in public consciousness);

4) relation of the local literature to the development of foreign literatures (cultures).

This view of literary history derived from the Slovak structuralist poetics tradition also had an impact on the thinking of Anton Popovič (1933-1984). Bakošs younger colleague, Popovič, specialized in Russian and comparative literature and researched the impact of Russian literature on Slovak literature in the $2^{\text {nd }}$ half of the $19^{\text {th }}$ century (1963). Popovič, who has come to be regarded as the founder of Slovak translation studies and one of the co-founders of 
descriptive translation studies (Djovčoš, Perez 2017), is often remembered because of his rigorous treatment of translation theory with an emphasis on clear conceptual frameworks and terminology (see Valentová 2017) and his organizational skills in collaborative research (see Bednárová 2017). This was due to his deep knowledge of structuralism and its research practices from the 1930 . He started off his career in the early 1960 s with empirical research of literature reception where he discovered the deep impact of $19^{\text {th }}$ century translations of Russian Realist literature on the Slovak literary canon. This was basically - and not incidentally - translation history. In order to gauge the historical impact of translation, he needed to examine the relation between text analysis and literary history. This research interest became a recurring topic in Popovičs work: "Popovič was a very complex scholar whose thinking grew out of methodology of sciences, and, drawing on both synchronic and diachronic aspects, he moved on to text interpretation and to seeing text as a theoretical problem. In other words, he moved from the particular and the concrete to abstractions, from surface descriptions to deep-level analyses." (Bednárová 2017: 25).

Explaining this relation became the theoretical foundation of his second monograph, Preklad a výraz (Translation and Expression, 1968a) whose publication, we believe, marks the beginning of Slovak translation studies as an autonomous discipline in the Slovak tradition. In this book, Popovič sought to interconnect historical poetics, literary text interpretation, and communicative approaches to literature to create a model for the historical research of translation. It is noteworthy to briefly outline his sources and influences at this stage.

Literary text interpretation became the flagship topic of the so-called Nitra School, which in 1967 found institutional roots at the Cabinet of Literary Communication at the local pedagogical faculty. The young, at the time rather inexperienced team, lead by Popovič interested in translation and František Miko (1920-2010), the author of a unique functional theory of stylistic categories (see Gromová, Müglová 2014), created an interdisciplinary research platform based on literary interpretation and literary communication. From the get-go, the team wanted to collaborate internationally, so Popovič got in touch with Polish literary scholars whom he knew from his research stay at Warsaw University. Their presence at the September 1967 seminar in Nitra was felt and arguably had an outsize influence on the young Nitra group. As Miko later recalled, "The Polish guests [namely E. Balcerzan, the Sławińskis, M. Głowiński] came with gifts [in 1967]: the concepts of interpretation and communication (our own methods of reading literary texts were not as advanced at the time)" (Miko 1990: 9, after Valentová 2017: 93). 
Another major influence on Popovičs thinking about translation and its history in the 1960 s were the works of the Czech translation scholar Jirrí Levý (1926-1967). Levýs first contribution to translation studies was also to translation history. This was his 1957 book České theorie prekladu (Czech Translation Theories) which was very positively received and in many ways sparked discussions about translation problems (mainly in Slovakia, see Tyšš 2017). The book was the first one in the field to address the dynamics between claims about translations and actual ways of translating, between norms and poetics, and to show how translation has contributed to the formation of cultural spaces. However, Popovič wanted to move even further and address the issue of objective style evaluation as a means of gauging the impact of translation in literary history. This is why he acknowledged that Levý's 1957 book helped "determine the value of the text according to the standards of the translator's contemporaries", but argued that the Czech scholar "was not so much interested in tracing how like or unlike the individual poetic natures of an author and his translator may have been" (1968b: 70). Clearly, Popovič was not aiming to reflect theories of particular historical periods, but to create a comprehensive theory which would enable him to objectively describe and evaluate individual translation practices in their historical development.

All of the mentioned sources and influences are reflected in Popovič's 1968 Preklad a výraz. From his later books, Popovič might very well seem to be a writer of complex, at times even convoluted, scientific prose with long, wellthough out sentences, systematic terminology (mostly) of his own creation; his explanations are almost solely deductive, and he uses empirical material for primarily illustrational purposes; his books contain many graphs, schemes, and even glossaries of terms. This is no way true for Preklad a výraz. When reading the book, one cannot avoid the impression of "stutter", incompleteness, and even uncertainty. Even though the book came out in a well established scientific publishing house and surely must have gone through a rigorous editing and proofreading process, it contains surprisingly many typos and even some grammatical errors. Also uncharacteristically for Popovič, who is known for his rather lackluster use of in-text references, he did use references so extensively that they can help us to reconstruct his network of influences. Quite notably, there are many references to Polish sources, for example to Ingarden's indeterminacy when explaining shifts; or Głowiński’s theories about understanding text when Popovič talks about interpretation and the virtual recipient; to Sławiński's concept of authorial subject when explaining the translatorial subject; and to Balcerzan when discussing the translator's stylistic attitudes. All in all, the book Preklad a výraz looks like Popovič's attempt to find his way through 
the maze of contemporary literary studies and demarcate the field of inquiry and conceptual framework for translation theory (and history).

Even though Popovič did not conduct any empirical research on translation history after 1971, when he published the monograph Poetika umeleckého prekladu (Poetics of Literary Translation), his personal archives and the testimonies of his associates (see Valentová 2017) prove that he still tried to instigate and organize historical research both in Slovakia (in a small research team at the Institute of World Literature) and internationally (from 1976 to 1982, an office of the international ICLA Committee on Translation History and Theory operated in Nitra). In the 1970s, Popovič mostly sought to theoretically systematize translation as communication on the basis of treating it as text and metatext (see Valentová 2017). In such an approach, he wanted to connect the communicational approach with cultural semiotics inspired mostly by the Tartu-Moscow Semiotic School.

This in absentia influence of A. Popovič on translation history research continued until his sudden death in 1984. In that decade, he helped put together the "primarily translation studies" (Valentová 2017: 43) dictionary Originál/preklad (Original/Translation, 1983) in which a group a contributors sought to outline the full scope of communicational, stylistic, semiotic, and translation theories developed by the Nitra School. It is in this dictionary that Popovič provides us with the fullest definition of translation history. He defines translation history in the broad and narrow sense. In the broad sense, he views it as the diachronic "modeling of the translation process", and, as such, translation history should be considered part of a national literature history. In the narrow sense, he defines translation history as the history of translation programs, formulated approaches to translation, and translation methods. Defined in this manner, translation history overlaps with comparative literature and stylistics. Popovič then presents this step-by-step translation history model which he says is the result of interconnecting the development of translation methods with general historical poetics (1983: 270-1):

A. Pilot studies and preliminary research

1. A bibliographic survey of translations

Statistics of manuscript, magazine, and book translations (on the basis of genre, authors, source literature, and literary epochs)

2. A bibliographic survey of translators - a dictionary of national translators

Differentiating between translators: 
a. Translators who are also writers

b. Translators who only specialize in translating

B. Praxeology [sociology] of translation. External conditions and sociocultural determinants of translating

C. Development of translation methods

1. History of translation programs

2. History of translation methods in various epochs

a. Formulated poetics of translation

b. Poetics of translation (dynamics between process and text). Relations: original - translation and translation - translation

D. Role of translation in literature development

1. Translation in the context of original works

a. Stylistic approaches in original works in translation and vice versa

b. Genres in literature and translation

E. Functions of translation in the literary system

1. Translations as facts of interliterary communication

2. Translation as part of the metaliterary system, i.e. literary education

3. Translation in the context of literature, philosophy, culture, etc.

F. Typology of national translation in various epochs in comparison to other national literatures

This model can be seen as a broad research program which many later individual researchers or even whole research groups have adopted, adapted, taken inspiration from, taken into account (see Kusá 2005, Bednárová 2013), or at least referenced. This model of translation history research takes cues from the semiotic-communicative theory of translation, but it mainly accounts for the social effect of translation (a phenomenon which today has been called "translation effects") and the translator's role (see Chesterman 2009 - translator studies). It is a very open, empirical, step-by-step blueprint for building a top-down Slovak translation macrohistory from individual microhistorical case studies.

\section{Translation history recent past and present}

In terms of the scope of the topics covered, present-day Slovak translation history research has brought two types of research outcomes (see more broadly in Tyšš 2017). There are, on the one hand, what we may call macrohistories of 
translation which are works covering rather broad topics and researching extensive material. They mostly deal with what can be seen as "central" (in the sense covered by Even-Zohar 1990) literary and translation activities and focus on the most significant (whatever that may be) and canonical translation products or processes (more often than not on book translations). On the other hand, current Slovak research has produced translation histories which Adamo (2006) or Munday (2014) would call microhistories of translation in that they focus on the dynamic "peripheries" of the literary and translation fields (with the most notable example of literary magazines), on the stories of individual translators, or very minute archival research. Of course, the two tendencies overlap.

\subsection{Macrohistories of translation}

As for the macrohistorical approach, this can be most clearly seen in Bednárovás Dejiny umeleckého prekladu na Slovensku I (Literary Translation History in Slovakia I, 2013). This is a synthetic work in which the author treats translation both as product by examining translation corpora, and as process of discursive practice deeply embedded in the target culture. The book covers the development of Slovak translation of sacred and religious texts (of various religions) in its gradual shift from word-for-word rendering out of respect for the sacredness of the holy word to more looser approaches which in effect opened up the way for literary translation. Since many religions shaped the history of the Slovak cultural space, the author employs a primarily thematic approach and thus lets the history speak for itself. The book also covers a whole range of social and historical factors pertaining to the Slovak translation space (e.g. different Christian denominations, languages of translation, geopolitics, etc.) which constitute an important framework for further research.

A second noteworthy macrohistorical project is the two-volume Slovnik slovenských prekladatelov umeleckej literatúry - 20. storočie (Dictionary of Slovak Literary Translators of the $20^{\text {th }}$ Century, Kovačičová, Kusá 2015, 2017). It could be argued that this monumental work organized and led by the Institute of World Literature sAs in collaboration with several researchers from Slovak universities continues in the tradition of interdisciplinary and collaborative research spearheaded by Bakoš and Popovič. The dictionary covers almost 400 Slovak literary translators active in the $20^{\text {th }}$ century. They have been included in the dictionary based on the number of book translations they produced and the significance of their translations. Naturally, the significance factor remains problematic, but the book itself is a great contribution to Slovak translation history. This is mainly due to the depth and scope of the material covered and 
the structure of the publications which allows for multiple ways of reading. When read synthetically, one comes to realize that the history of translators is a history of translation and indeed a cultural history of Slovakia in the $20^{\text {th }}$ century. When read selectively using the rich indexes, one can examine the translations of particular foreign authors or literature.

Another type of Slovak translation macrohistories lies at the confluence of comparative literature and translation history, since translation is arguably the most noticeable demonstration of interliterary contact. This research venue has been pursued since the 1990 s by the Institute of World Literature in Bratislava. Here experts on individual foreign literatures have produced a steady stream of well informed publications. Since the late 1990s, the research at the Institute has focused even more on translation. This change seems to have been one of gradual development (see Kusá 2009), and its results are showcased in the book edition "Stručné dejiny umeleckého prekladu" (Brief Histories of Literary Translation). One of the most recent examples of this line of research is the very important survey of Russian literature translations in Slovak culture edited by Kusá (2017).

\subsection{Microhistories of translation}

When looking at the present Slovak research in translation history, we can argue that this type of research, which is naturally smaller in scale, tends to be conducted by individual researchers and mostly (not exclusively) at universities (where some of it has appeared even in students' theses). This is mainly due to the institutional constraints of the Slovak universities where staff have to divide their work time between research, teaching, and thesis supervision. As for the methodology such research employs, it has come out mostly in the form of more or less formalized historical case studies. Due to spacial constraints of the article format, we shall only mention three publications which we consider noteworthy for an international readership.

Pliešovskás 2016 monograph Od Buckovej k Updikovi (From Buck to Updike) is a history of Slovak translations of American literature in 1945-1968 viewed through the responses to the translation in the form of magazine reviews and translation critiques. This makes the book a unique example of a translation historical reader response study.

Tyššs (2017) book on the Slovak translations of Beat poetry is a social historical survey of translation. By viewing the reception of the said literature in the historical and social space of a popular 1960s Slovak literary magazine, he manages not only to document the responses to the translation but recon- 
struct the power and cultural dynamics of the era, and thus look not only on translation history but also on translation in history.

Another interesting example of a translation microhistory is Ján Vilikovskýs Shakespeare u nás (Shakespeare in Slovakia, 2014) where the author discusses the history of translating Shakespeare's plays and sonnets into Slovak from the $19^{\text {th }}$ century to today. He addresses not only the historical development of various Slovak translational approaches to Shakespeare's works but also contextualizes the translations within the developmental arc of Slovak literature. What makes the monograph noteworthy is the fact that the author views Shakespearean translations not as mere translational artifacts but also as cultural and historical phenomena and looks at the material from various scholarly perspectives (English studies, translation studies, literary studies, translation theory, and criticism) aided by his rich experience as a renown translator.

\subsection{Current Slovak research venues in translation history}

Based on our bibliographic research and the survey we conducted, we shall now briefly discuss the current research trends in Slovak translation history. We shall supplement our discussion with some of what individual researchers have said in our survey.

In terms of macrohistory, the trend in Slovakia seems to be toward synthetic translation histories, as witnessed mostly by research conducted at the Institute of World Literature and most notably by Katarína Bednárová in her literary translation history series (at present she is working on a volume dedicated to documenting the historical shift from utilitarian to literary translation). Another important streak is the comparative literature (or reception) based research of translation history, as seen in the work of Libuša Vajdová, Mária Kusá, K. Bednárová, and several others.

The research of translation history rooted in historical poetics started by Bakoš and his Bratislava colleagues still continues, with Anna Valcerovás deep and numerous reflections on the generational poetics of the most accomplished group of poet-translators of the 1960s; Ladislav Franek's use of the Slovak and Czech versological tradition in his insightful historical analyses of Slovak poetry translations from French and Hispanic literatures; and Ján Zambor using his own rich practical experience with poetry translation and his knowledge of historical poetics to critically and historically interpret the development of poetic form of Russian and Hispanic poetry translated into Slovak.

Major research initiatives continue in the examination of what we may broadly term translation theory history. Here, Edita Gromova focuses on the 
impact of Popovičs heritage and the research of the Nitra School; Mária Valentová has deployed archival research in her broad investigations of the Nitra School to contextualize Slovak translation history in the tradition of Slovak structuralism, semiotics, and text theory. Important contributions have also been made by Bednárová and Kusá. L. Vajdová, who has managed to straddle both the comparative literature and translation studies tradition, has presented a very vivid picture of the motivating potential of Slovak translation studies and comparative literature tradition. Her historically critical take on the concept of receptive tradition (2009) remains a must-read for Slovak translation historians.

Newer research venues include sociological research of translation history which focuses not only on the social aspects of translation history or histories of translation as a social practice, but also rather unconventional sociological examinations of translation theory history (like Djovčošss and Tyššss 2018 look at Levýs contribution to translation sociology). Important research has also recently been conducted in examining the history of Slovak translation criticism which has had a formative impact on Slovak thinking about translation (Lubica Pliešovská and mainly Matej Laš). Given the socialist past of Slovakia, many younger translation scholars are also interested in ideology, discourse, and forms of patronage in that era, as seen in the research conducted by Mariana Bachledová or Igor Tyšš. An interesting recent streak of research is the history of audiovisual translation (Miroslava Brezovská, I. Tyšš).

\subsection{What is (possibly) to come: translation history future in Slovakia}

In this part, we shall briefly discuss the tendencies we have observed very recently and consider promising in the light of what has been going on in translation studies outside Slovakia. We cover the research prospects to the best of our knowledge and apologize beforehand for not including everything - our data is limited to our survey and personal knowledge.

More and more research is being conducted with the focus on the individual translators, as signaled by the already mentioned dictionaries of translators. Researchers are starting to look at translators' agency, their roles, and even the traditional concept of the translator's poetics is being looked at from the standpoint of power relations. Another important streak of research, instigated by Martin Djovčoš at Matej Bel University (MBU) in Banská Bystrica, is the research of the translator's invisibility and marginalization during socialism. The researchers in Banská Bystrica are also planning to publish extensive interview material with notable Slovak translators which would no doubt help instigate more research of translation oral history. The Bratislava-based Institute of World Literature, 
whose K. Bednárová and M. Kusá have led many major translation history research projects, has started focusing on translated texts lying on the intersection between literary and non-literary genres (such as literary studies, philosophy, aesthetics, etc.) and on literary and social institutions (such as publishing houses, literary magazines, conferences, universities, etc.) as part of translation history.

What we see in recent and planned Slovak translation history research is that translation history more often than not overlaps with other areas of research (very prominently with translation sociology); the research also tends to give more room to the examination of the translation process and practice; some of the best research of translation history is often so empirically grounded and well researched that it has the potential to merge into history proper.

\section{Conclusion}

So, what should one take from all of this? Have we in Slovakia just followed the research plans and models set out by our forefathers, or have we also, so to say, taken research into our own hands and engaged in paradigm-shifting rebellion?

After having taken stock of the depth and scope of past, present, and (possible) future Slovak translation history research, we are in awe of how extensive it is. The models of historical research set up by (among others) Bakoš and Popovič were never intended as strict programs. They were supposed to remind younger scholars at the time of the breadth of the problems and help them organize their thinking and methodology when overwhelmed with huge swaths of historical material. The models were never set in stone, and nor has there been one set approach to translation history. Bakoš and Popovič were definitely not the only scholars at the time who formulated research models.

In our survey, we have asked Slovak translation history researchers (not all of them consider themselves translation historians, which is also telling) to tell us their working definitions of translation history. It astonished us when we saw that their definitions effectively overlapped in their open-mindedness to accept a complexity of problems and a rich set of possible methodologies. This is how one younger scholar, Mariana Bachledová from MBU Banská Bystrica, sees translation history (emphasis ours):

Translation history is the history of text (i.e. material and reception research), but also of people (sociological and historiographical research). Translation history should also cover the development of thinking about translation (and in Slovakia also the impact of ideology 
on theory), the choice of works to be translated, choice of who should translate, the editorial process, the development of translation methods [...], teaching translation, praxeology of translation, the market, social labels, the status, and personal stories of translators.

It is remarkable how her view coincides with the view of the older translation scholar Mária Kusá who says the following about translation history:

I consider translation history an inseparable part of a particular local cultural history. Briefly put, translation history encompasses all quantitative and qualitative research and reflection of translation, along with the examination of its [historical] circumstances, forms, and functions in a given cultural space.

It is not surprising in this context that another younger translation scholar, translation sociologist Martin Djovčoš, who also on occasion delves into historical research, mentions the need for history to inform the present: "I think it is impossible to study translation history without looking at the current translation practice."

We think that the greatest inheritance current Slovak translation history research has been given from its past is not only the richness of concepts, material, and methodologies, but mainly the work ethic which has always been one of collaborative coexistence between older and newer approaches and the older and the younger generation of scholars. This environment of collaboration has given rise to a number of joint research projects, many jointly held conferences, and collaborations on particular occasions (including this one here).

Future Slovak translation history will be empirical because so much empirical research has already been done, and the best young scholars are growing more aware of not just what has been done, but, more importantly, of what has not been covered fully or needs to be done altogether. The historical research will bring important results, since past research has clearly established that translation played an important role in the shaping of the Slovak cultural space. Finally, the most progressive future research will definitely go beyond translation studies to a study of translation in history. This will in no small degree be thanks to the past influencing the present: the already established tendencies toward collaborative and interdisciplinary research; questioning and open-minded approaches to the material which have already become standard practice.

Based on the state of the Slovak field of translation history and predominant practices within it, we claim that Slovak translation historians have indeed taken 
matters into their own hands. We might even go as far as to allow ourselves this little persiflage in the homage of James S. Holmes (1988): The meta-discussion about Slovak translation history has successfully begun, and it will no doubt continue into the future.

\section{| References}

Adamo, Sergia. "Microhistory of Translation". Charting the Future of Translation History. Ed. by Georges L. Bastin and Paul F. Bandia. Ottawa: University of Ottawa Press, 2006. Pp. 81-100.

Bagin, Albín. Vitalita slovesnej tvorby. Bratislava: Tatran, 1982.

Bakoš, Ján. "Štrukturalizmus na slovensku ako symbolický skok". Od iniciatívy $k$ tradícii. Štrukturalizmus v slovenskej literárnej vede od 3o. rokov po súčasnost'. Ed. by Fedor Matejov, Peter Zajac. Brno: Host, 2005. Pp. 286-297.

Bakoš, Mikuláš. Avantgarda 38. Štúdie, články, dokumenty. Bratislava: Slovenský spisovatel', 1969 a.

Bakoš, Mikuláš. Literárna história a historická poetika. Bratislava: Ústav svetovej literatúry a jazykov Slovenskej akadémie vied, $1969 \mathrm{~b}$.

Bakoš, Mikuláš. Problém vývinovej periodizácie slovenskej literatúry. Trnava: Fr. Urbánek a spol., 1944.

Bakoš, Mikuláš. Vývin slovenského verša od školy Štúrovej. 3rd ed. Bratislava: Vydavatel'stvo Slovenskej akadémie vied, 1966.

Bastin, Georges L., Bandia, Paul F. "Introduction”. Charting the Future of Translation History. Ed. by Georges L. Bastin, Paul F. Bandia. Ottawa: University of Ottawa Press, 2006. Pp. 1-9.

Bednárová, Katarína. "Anton Popovič: between comparative literature and semiotics". World Literature Studies 9:2 (2017). Pp. 21-37.

Bednárová, Katarína. Dejiny umeleckého prekladu na Slovensku I. Od sakrálneho k profánnemu. Bratislava: vEDA, 2013.

Chesterman, Andrew. "The Name and Nature of Translator Studies". Hermes Journal of Language and Communication Studies 42 (2009). Pp. 13-22.

Djovčoš, Martin; Perez, Emília. "Bridging the mental Iron Curtain, or, re-exploring the 'old' in new contexts”. World Literature Studies 9:2 (2017). Pp. 3-11.

Djovčoš, Martin; Tyšš, Igor. "Levý a sociológia prekladu? Inšpirácie a paralely - náčrt problematiky”. AUC Philologica 2/2018. Ed. by Jana Králová and Kateřina Stř̌edová. Praha: Karolinum, 2018. Pp. 43-58.

Even-Zohar, Itamar. "Polysystem Studies". Poetics Today 1:11 (1990). Pp. 1-6. 
Foucault, Michel. “The Order of Discourse”, Trans. by Ian McLeod. Untying the Text: A Post-Structuralist Reader, Ed. by Robert Young. Boston; London; Henley: Routledge; Kegan Paul, 1981. Pp. 51-78.

Franek, Ladislav. "Slovenská literárna veda a Mikuláš Bakoš”. Mikuláš Bakoš a moderná literárna veda. Ed. by Dušan Teplan. Nitra: Univerzita Konštatnína Filozofa, 2016. Pp. 29-40.

Gáfrik, Róbert. "Mikuláš Bakoš a osud ruského formalizmu na Slovensku”. Mikuláš Bakoš a moderná literárna veda, Ed. by Dušan Teplan. Nitra: Univerzita Konštatnína Filozofa, 2016. Pp. 85-95.

Gromová, Edita; Müglová, Daniela. “František Miko’s theoretical heritage in the Nitra School of Translation: Perspectives and Retrospection". Gegenwärtige Translationswissenschaft in der Slovakei, Ed. by Zuzana Bohušová and Anita Hutková. Wien: Praesens, 2014. Pp. 17-33.

Holmes, James S. “The Name and Nature of Translation Studies”. Extended version. Translated! Papers on Literary Translation and Translation Studies. Amsterdam: Rodopi, 1988. Pp. 66-8o.

Koperski, Jeffrey. "Models”. Internet Encyclopedia of Philosophy. 2019.

Web. 10.10.2019.

Kovačičová, Olga; Kusá, Mária, ed. Slovník slovenských prekladatelov umeleckej literatúry - 20. storočie. A - K. Bratislava: vEDA, 2015.

Kovačičová, Olga; Kusá, Mária, ed. Slovník slovenských prekladatelov umeleckej literatúry - 20. storočie. $L-\check{Z}$. Bratislava: VEDA, 2017.

Krupa, Viktor. Metafora na rozhraní vedeckých disciplín. Bratislava: Tatran, 1990.

Kusá, Mária, ed. Ruská literatúra v slovenskej kultúre v rokoch 1825-2015. Bratislava: VEDA, 2017.

Kusá, Mária. "Current State of the Slovak Thinking on Translation”. World Literature Studies 4:1 (2009). Pp. 3-15.

Kusá, Mária. Preklad ako súčast dejín kultúrneho priestoru. Bratislava: Ústav svetovej literatúry SAV, 2005.

Levý, Jiří. České theorie překladu. Praha: Státní nakladatelství krásné literatury, hudby a umění, 1957.

Marcelli, Miroslav. Michel Foucault alebo Stat'sa iným. Bratislava: KALLIGRAM, 2005.

Marušiak, Juraj. Slovenská literatúra a moc v druhej polovici pät'desiatych rokov. Brno: Prius, 2001.

Matejov, Fedor; Zajac, Peter. "Štrukturalizmus v slovenskej literárnej vede”. Od iniciatívy $k$ tradícii. Štrukturalizmus $v$ slovenskej literárnej vede od 3o. rokov po súčasnost. Ed. by Fedor Matejov and Peter Zajac. Brno: Host, 2005. Pp. 7-21. 
Munday, Jeremy. "Using primary sources to produce a microhistory of translation and translators: theoretical and methodological concerns". The Translator 20:1 (2014). Pp. 64-80.

Pliešovská, L’ubica. Od Buckovej k Updikovi. Americká literatúra na Slovensku $v$ rokoch 1945-1968. Banská Bystrica: Belianum, 2016.

Popovič, Anton. "Dejiny prekladu”. Originál/preklad. Interpretačná terminológia. Ed. by Anton Popovič. Bratislava: Tatran, 1983. Pp. 270-1.

Popovič, Anton. "Translation Analysis and Literary History: A Slovak Approach to the Problem". Babel 14:2 (1968b).

Popovič, Anton. Poetika umeleckého prekladu. Proces a text. Bratislava: Tatran, 1971.

Popovič, Anton. Preklad a výraz. Bratislava: Vydavatel'stvo Slovenskej akadémie vied, 1968a.

Popovič, Anton. Ruská literatúra na Slovensku v rokoch 1863-1875. Bratislava: Vydavatel'stvo Slovenskej akadémie vied, 1963.

Rizzi, Andrea; Lang, Birgit; Pym, Anthony. What is Translation History?

A Trust-Based Approach. Switzerland: Palgrave Pivot, 2019.

Rundle, Christopher. "Translation as an approach to history". Translation Studies 5:2 (2012). Pp. 232-240.

Saldanha, Gabriela; O’Brien, Sharon. Research Methodologies in Translation Studies. London; New York: Routledge, 2013.

Snell-Hornby, Mary. The Turns of Translation Studies. New paradigms or shifting viewpoints?. Amsterdam; Philadelphia: John Benjamins, 2006.

Tyšš, Igor. Teoretické a materiálové sondy do praxeológie a dejín prekladu na Slovensku v období socializmu. Mladá tvorba a Beat Generation. Nitra: Univerzita Konštantína Filozofa v Nitre, 2017.

Vajdová, Libuša. Sedem životov prekladu. Bratislava: veDA, 2009.

Valentová, Mária. Modely umeleckej komunikácie v kontextoch histórie Nitrianskej školy. Dissertation thesis. Nitra: Ústav literarárnej a umeleckej komunikácie FF UKF v Nitre, 2017.

Vilikovský, Ján. Shakespeare u nás. Bratislava: Divadelný ústav; Slovart, 2014.

The research for this study has been conducted as part of and funded by the scientific research grant VEGA No. 2/o166/19 2/0166/19 Preklad ako súčast' dejín kultúrneho procesu III (Translation as part of cultural process history). 


\title{
| Abstrakt \\ Igor Tyšš, Edita Gromová \\ Jak wziąć sprawy w swoje ręce: humanizacja słowackiej historii tłumaczeń
}

Historia tłumaczeń zawsze była bardzo ważna dla słowackiej literatury i badań nad tłumaczeniami. W niniejszym artykule omawiamy początki słowackiej historii badań nad tłumaczeniami, których korzenie odnajdziemy w formalizmie i strukturalizmie. Również poddajemy rekonstrukcji linie wpływów aż do obecnych czasów, w których historię tłumaczeń można opisać jako żywą, otwartą, interdyscyplinarną i empiryczną dziedziną. Biorąc pod uwagę również przeszłość, przyglądamy się kilku najnowszym i najistotniejszym słowackim inicjatywom w historii badań nad tłumaczeniami i oceniamy ich potencjał na przyszłość.

Słowa kluczowe: historia tłumaczenia, Słowacja, strukturalizm, badania

\begin{abstract}
| Abstract
Igor Tyšš, Edita Gromová

Taking Matters into our own Hands: Humanizing Slovak Translation History

Translation history has always played an important role in Slovak literary and translation studies. In our paper we discuss the beginnings of Slovak translation history research, which have their roots in formalism and structuralism, and reconstruct lines of influence to the present when translation history is a lively, open, interdisciplinary, and empirical discipline. With the past in mind, we look at several of the most recent and significant research initiatives in Slovak translation history research and evaluate their potential for the future.
\end{abstract}

Keywords: translation history, Slovakia, structuralism, formalism, research

| Bio

Igor Tyšš works at the Department of Translation Studies FA CPU in Nitra. In his research he deals with translation history, poetry translation, translation criticism, and the impact of communist ideology on translation. He also works with cognitive and phenomenological linguistics. He was a research consortium member 
for The Evolution of Semantic Systems project, run by the Max Planck Institute for Psycholinguistics, and took part in research conducted at Goethe University Frankfurt. He also collaborated on a number of larger Slovak research projects (mainly focusing on translation history).

Email: ityss@ukf.sk

ORCID: 0000-0002-3172-9369

Edita Gromová is a professor at the Department of Translation Studies, Faculty of Arts, Constantine the Philosopher University in Nitra. Her main research interests are translation studies, translation theory and didactics. She has participated in many research projects in Slovakia and abroad. She is the author of numerous publications in the field. She is a member of several editorial boards. In 1998-2014 she was the vice-chairperson of The Slovak Society of Translators of Scientific and Technical Literature (SSPOL) and in 2011 a representative of her university in the European Master's in Translation (Емт) and was a member of the EMT Network Board in 2011-2014.

Email: egromova@ukf.sk

ORCID: 0000-0001-6181-2043 